\title{
Genetic Impact Determination of Farmed Fish on Native Fish by mtDNA Markers
}

\author{
Ali KAYACI ${ }^{1}$, Mehmet Fatih CAN ${ }^{2}$, Yusuf GUNER ${ }^{2}$, Fatih GULEC ${ }^{3}$, Mehmet IKIZ ${ }^{3}$ \\ ${ }^{1}$ MKU, Faculty of Marine Science and Technology, Aquaculture Department, Hatay/TURKEY \\ ${ }^{2}$ MKU, Faculty of Marine Science and Technology, Seafood Catching and Processing Department, Hatay/TURKEY \\ ${ }^{3}$ Ege University, Faculty of Aquaculture, Aquaculture Department, Bornova, zmir/TURKEY
}

\section{Received (Geliş): 06.06.2014}

Accepted (Kabul): 02.02.2015

\begin{abstract}
Aquaculture is one of the world's fastest-developing and growing food-producing sectors. The subsector's expansion commenced in the 1970's, actuated by move forwards in hatchery technology and pond husbandry. Aquaculture and especially fish farming, however, have been discussed as negative potential effects on environment. The negative potential effects are, direct mortality, loss of biodiversity, tainting of wild species. Moreover these are disease transmission to other species, displacement of wild fish from natural habitat.

Although these negative potential effects, cultural fish represent genetically exogenous populations or crosses between them. Some pauper gen pool of cultured fish population can develop with fertile gen pool of natural fish population or just the opposite of them.

It can be said that cultured fish typically constitute gene pools. We need an observation which brings an urgent focus for conservation between natural populations and spawning populations. In this review it was observed negative genetic impacts of escaped farmed fish population on wild fish population by mtDNA markers.
\end{abstract}

Keywords: Genetic impact, escaped farmed fish, molecular markers, mtDNA markers

\section{INTRODUCTION}

Aquaculture has elaborated rapidly over the decades due to growing in the world population. Especially, the growing trend in aquaculture has expanded enormously since 1970's (Brugère and Ridler, 2004; Tacon, 2003; Duarte, Marba \&Holmer, 2007; Flassch and Leborgne, 1994). Aquaculture is not applied only for consumption, but also is applied for recreation, decoration, bio manipulation, the protection of threatened species and research (Welcomme \& Bartley, 1998; Utter \& Epifanio, 2002). Inevitably, fish is the most important source of protein for many people, especially in the developing locations of the world (Rodwell et al., 2003). In addition to this, it has substantial activity for economy, providing jobs and investment opportunities (Smith, 2007).

The aquaculture activities has positive contributions, although, it has been lead to some problems, such as habitat destruction, blockage of migration routes, and changing of genetic structure of native fish stocks (Ferguson et al, 1995). Many cultured fish species used in aquaculture are usually genetically different from local wild populations. In the case of escape from the aquaculture sites, the breeding of escaped fish with native ones have result in genetic changes in wild populations. The attempt has been focusing on understanding of the process of changes in genetics of wild population using mitochondrial DNA molecular markers. Because, genetic diversity measurement in wild fish populations is significant for understanding and effective management of these populations (Farias, 2001; Knibb, 2000; Okumus and Cifci, 2003; Aquilino et al., 2011; Cawthorn et al., 2011; Lakra et al., 2011;
Mecklenburg et al., 2011; Kartavtsev et al., 2009; Ward et al., 2005; Hubert et al., 2008; Nicolas et al., 2012).

Owing to increase the contingency that gene trees reverberate the topology of the species tree which is the true a taxons gene pool, phylogenetic hypotheses comprehended from many dissimilar and independently transmitted loci must be compared. Therefore, mitochondrial DNA (mtDNA) can use specification a phylogenetic analysis based on diversity within the fishes subfamily.

However, high resolution of many methods of DNA analysis, up to the probability to detect individualistic fish, including those aimed at detecting withinpopulation coactions. Based on mtdna, new approaches are developed to resolve the problems that were not solved by means of investigating fish morphology, physiology, and behavior.

\section{ESCAPED FARMED FISH}

Escapes of fish from sea-cage or inland water-cage aquaculture have typically been thought of as referring to juvenile and adult fish. Such escapes have been reported for almost all species presently cultured around the world, including Atlantic salmon Salmosalar, Atlantic cod Gadusmorhua, rainbow trout Oncorhynchusmykiss, Arctic charr Salvelinusalpinus, halibut Hippoglossushippoglossus, sea bream Sparusaurata, sea bass Dicentrachuslabrax, meager Angyrosomusregius and kingfish Seriolalalandi (e.g. Soto et al. 2001, Naylor et al. 2005, Gillanders\& Joyce 2005, Moe et al. 2007a, Toledo Guedes et al. 2009).

Jørstad (et al. 2008) focused on a second form of escaping, fertilized eggs spawned by farmed individuals from sea- cage facilities, or so-called 'escape through 
spawning. This situation caused a redefinition of the term 'escapes from aquaculture'. This new term should include the escapement of fertilized eggs into the wider marine environment (Jensen et al. 2010). Fish escape incidents from sea-cages have been reported for almost all species presently cultured across Europe, including many different ones. The amount of the fugitive fish has an important place on the ecological and genetic effects. According to Naylor (et al., 2005) escapes can have detrimental genetic and ecological effects on populations of wild conspecifics. Numbers about escapes incidents can be find in some researchers studies.
Farm fish escape may have an indirect impact on the genetic composition of wild populations. Ferguson (et al., 2007) claim this situation may appear due to behavioral, ecological and disease interactions with the wild population. He also claims that these reduce the success of wild fish population and increasing genetic drift. Beside this event, a serious problem may occur: diseases. They may come along from aquaculture and could have negative consequences for the long-term persistence of the species in the wild (De Eyto et al. 2007). Escapes from Norwegian salmon farms in 2002, 2003 and 2004 were shown in figure 1.

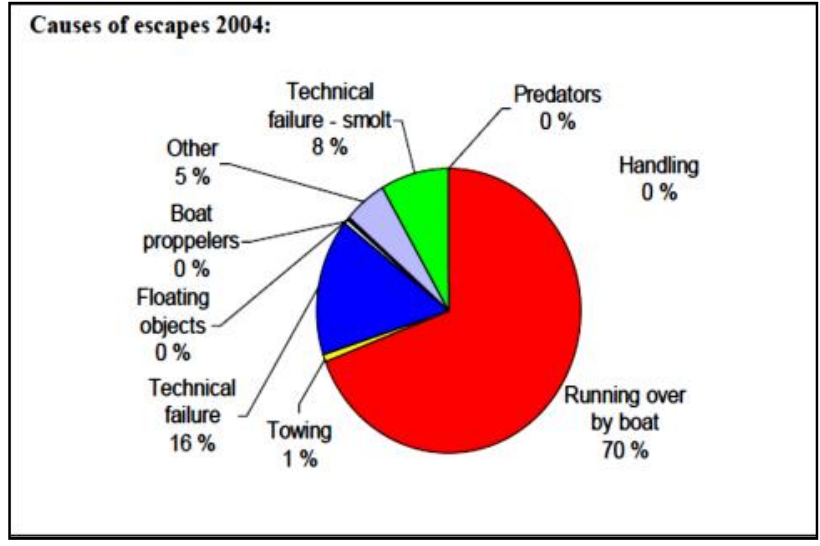

Figure 1. Causes of reported escapes from Norwegian Salmon farms in 2002, 2003 and 2004. Data source: Directorate of Fisheries. Figures from Valland (2005).

Aquaculture escapes are seen as a serious threat to wild fish populations. Lack of technical and operational failures in fish farming equipment causes escapes. For instance, 3.93 million Atlantic salmon Salmosalar, 0.98 million rainbow trout Oncorhynchusmykiss and 1.05 million Atlantic cod Gadusmorhua escaped from 2001 to 2009 in Norway (Jensen et al., 2010). Another problem about escapes is in topics of genetic and ecological effects. It is regarded as a problem for the

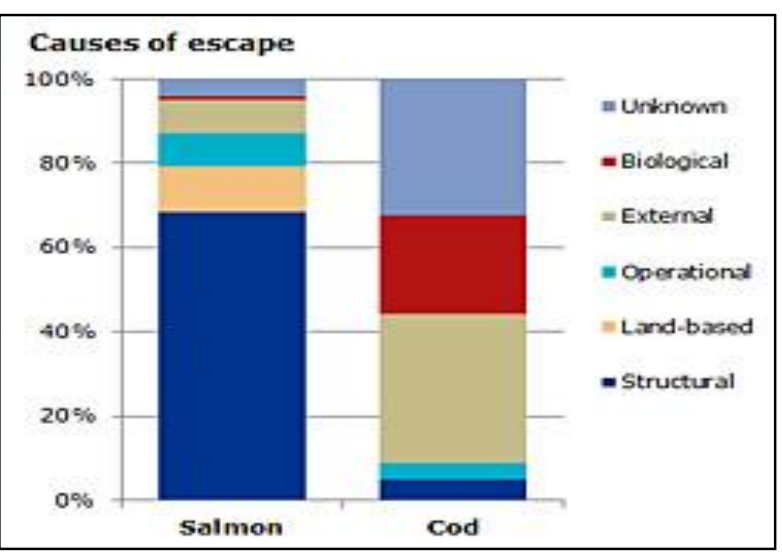

Figure 2. Causes of reported escapes farmed salmon and farmed cod fish in from 2006 to 2009. Data source: http://cdn.phys.org/newman/gfx/news/2013/1satellite(4).jpg

future sustainability of sea-cage aquaculture (Naylor et al. 2005). Naylor described this as a future sustainability of sea-cage aquaculture problem. Scientific Advisory Committee (2009) claimed over 325 million Atlantic salmon are held in sea-cages in Norway. It is known that large numbers of population fish are caged in farms. But wild fish population is lesser then caged fish. Here importance of escapement occurs about ecological and genetic impacts (Jensen et al 2010).
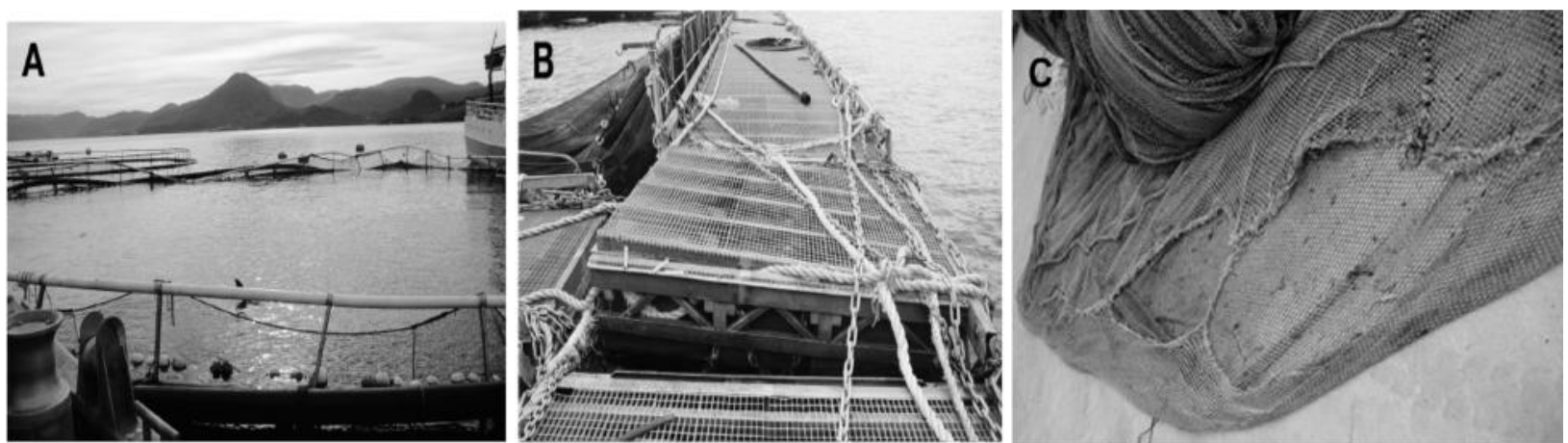

Figure 3. Examples of the major structural causes of escape incidents: (A) progressive mooring failure; (B) breakdown and sinking of steel fish farms; and (C) abrasion and tearing of nets. Photo: Jensen et al (2010).

Ecological interactions have genetic effects in cultured and wild fish interbreeding zone. Population interactions are dependent on the state of the wild population in terms of carrying capacity, genetic 


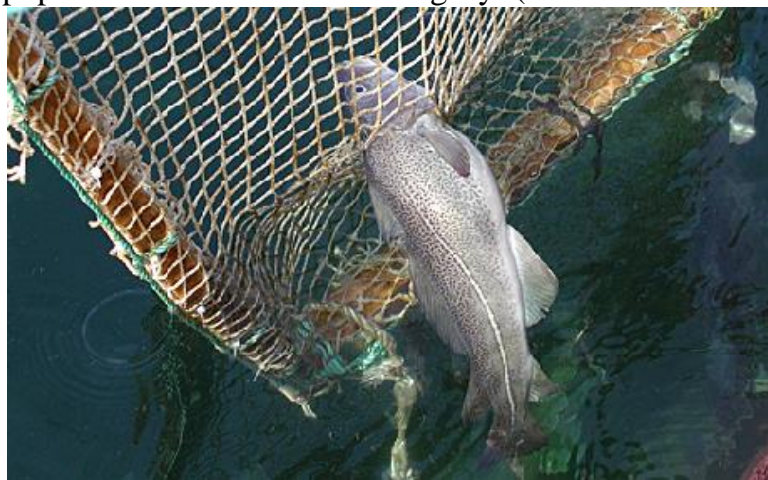

Figure 4. A clear sign of cod curiosity: Instead of swimming around a panel of netting, the fish has tried to swim through an impassable hole. Photo: Project on escape free net cages for cod. (http://cdn.phys.org/newman/gfx/news/2013/1satellite(7).jpg )

Accidental releases from sea cages may happen in aquaculture farms. In these cases of accidental escapes, massive numbers of fish enter the wild. Dimitriou (et al., 2007) claims market requirement for larger fish caused the release of gametes by gilthead sea bream spawners from the cages in the past. Related with this study, Sola (et al., 2007) studied on the impact of these activities on wild gilthead sea bream populations.

MtDNA Molecular Marker Used to Determine Genetics Distortion in Natural Fish Stocks

Mitochondrial DNA (mtDNA) analysis is being increasingly used in recent population and phylogenetic surveys of organisms. Brown (1985) studied on vertebrate species in literature. It was shown that sequence divergence accumulates more rapidly in mitochondrial than in nuclear DNA in his study. This causes to a faster mutation rate in mtDNA that may result from a lack of repair mechanisms during replication (Wilson et al., 1985). According to Briky (et al., 1989) it has smaller effective population size due to the strict maternal inheritance of the haploid mitochondrial genome. However, Meyer (1993) claims different parts of the mitochondrial genome are known to evolve at different rates in his study. Aquacultured Atlantic salmonis genetically different from local wild populations. They usually are being derived from geographically remote populations. (Cross and Challanain, 1991; Youngson et al., 1991).

37 years ago, ribosomal RNA sequences have been used for determination of species diversity (Woese and Fox, 1977). MtDNA molecular weight has become a target in the late 1980s (Avise 1994). In this scope mainly mitochondrial (mt) cytochrome b (Cyt-b), cytochrome oxidase subunit 1 (CO1) and 16S rRNAtargeted genes and species, genus and family separations could be done successfully (Baharum and Nurdalila 2012; Weight et al. 2012; Hebert et al., 2004). According another study, $16 \mathrm{~S}$ gene is 2.5 less variable

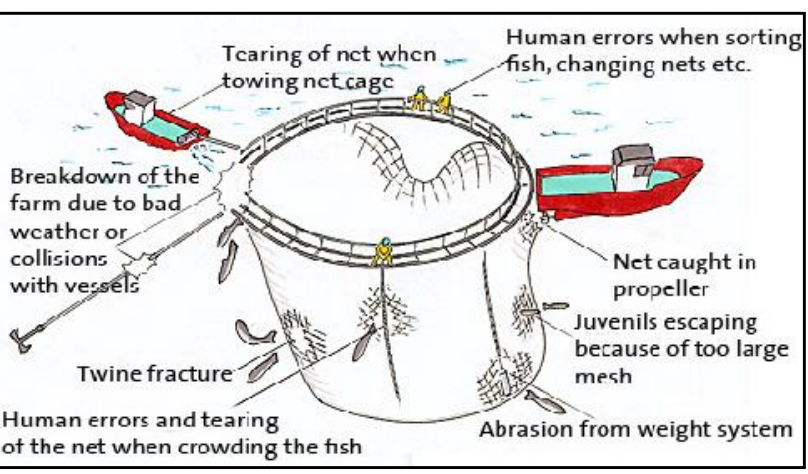

Figure 5. The illustration shows common escape factors with special focus on holes in the nets and sea-cage operations. Credit: Mats A. Heide, Sintef.

(http://cdn.phys.org/newman/gfx/news/2013/1satellite(6).jpg )

than the Cyt-b and CO1 genes. Here, it is seen that discriminatory power is smaller. Suggesting DNA markers for determining species in the Praomyini tribe is a valid approach using the CO1 and Cyt-b genesthan the 16S gene (Nicolas et al. 2012).

Martins et al.(2003) discussed the genetic variation of natural populations of $L$. elongates. Its aim was to present a preliminary assessment of the genetic variableness of six wild populations.

Research based on the nucleotide sequence of a segment of the non-coding control region (D-loop) of the mitochondrial genome. The results were useful for recovery efforts and to the biodiversity maintenance of this fish species.

During analyzing studies of mtDNA in European anchovy (Engraulisencrusicolus) a large number of mitotypes exposed two distinct clusters (phylads) (Magoulas et al, 1996). Phylogenetic analysis of Engraulisencrusicolus, mtDNA provides a reconstruction of population history in the Mediterranean, which is consistent with the geological information. Some points of phylogenetic analysis are given below.

- Phylad A consists of one common mitotype and many rare secondary mitotypes.

- Phylad B has a complex pattern of mitotype connectedness, high nucleotide diversity, and a large number of homoplasious changes.

- It is suggested that the two phylads evolved in isolation from each other is the result of a secondary contact.

Fish barcoding upgrade is made in many different geographical areas. MtDNA reflects a considerable degree of intra-species diversity (Aquilino et al.., 2011; Cawthorn et al.. 2011; Lakra et al.. 2011; Mecklenburg et al.. 2011; Kartavtsev et al., 2009; Ward et al.. 2005; Hubert et al.. 2008). 


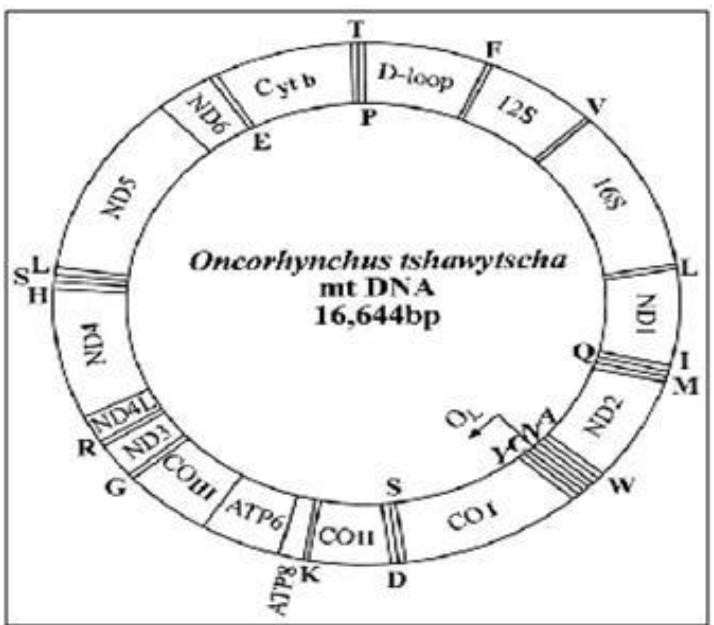

Figure 6. The organization of the mitochondrial genome of $O$. tshawytscha.

Photo: http://www.scielo.cl/fbpe/img/bres/v36n2/fig25.gif

Selective pressure and levels of inbreeding aquaculture, natural and non-artificial environment varies in the same. For this reason, the performance in terms of growth and survival of natural and cultural bream lines which might have different growing conditions. When there are not good genetic programs, regional fish farming enterprises insufficient selectivity studies and outnumbered in the breeding populations were trying to do with and is an unplanned selectivity intensive inbreeding has led to the emergence of farming. This situation has put pressure on the genetic diversity of wild populations to extinction even been reported to cause (Knibb, 2000).

Levels of selection pressures and inbreeding may vary in different natural and artificial environments. Therefore, wild and captive sea bream strains may take issue for growth and survival performance in immurement. Choice of the best existing strains could equal the genetic gains made by years of within-strain selection using inferior strains. Hence, strain testing should proceed within strain selection (Gjedrem, 1998). It seem that performance in captivity can be assessed only by direct experimental trials and cannot be predicted a priori by indirect measures of genetic

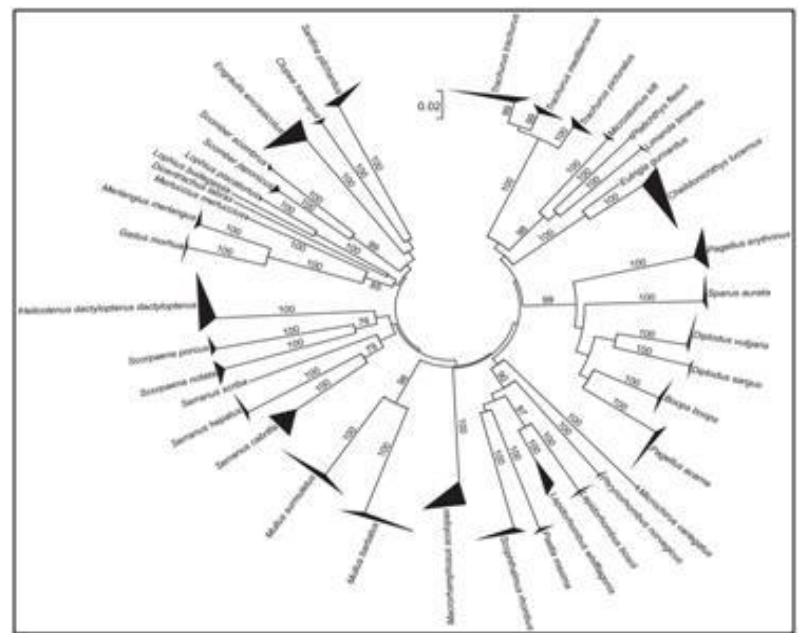

Figure 7. Phylogenetic analysis (cyt $b$ ). Neighbour Joining tree for partial sequences of the mitochondrial cytochrome $b$ gene of fishes from European seas.

Photo:http://www.plosone.org/article/fetchObject.action ?uri=info:doi/10.1371/journal.pone.0012620.g004\&repr esentation=PNG_I

variation, including allozyme, mitochondrial and microsatellite polymorphism (Bentsen and Gjerde 1994).

Bernatchez (et al., 1991) used mtDNA restriction analysis to assess phylogenetic patterns 21 taxa of the subfamily Coregoninae in his study. The genus Prosopium formed a very distinct group differing by 10 $\%$ (squence divergence estimate) from other species. Coregonus and Stenodus species were closely related, diverging by sequence divergence estimates of less than 5-6\%. In the other study, they show us that the brown trout Salmotrutta L. presents an elaborate pattern of morphological and life-history degree of diversity. This prevents the understanding of the evolutionary history of the species; it has led to significant taxonomic confusion.

The phylogenetic kinships among morphologically and relating to geography remote brown trout populations from side to side western Europe, they determined the DNA sequence variation in segments of the mitochondrial control area of activity for 151 individuals representing 24 populations (Bernatchez et al., 1992). 


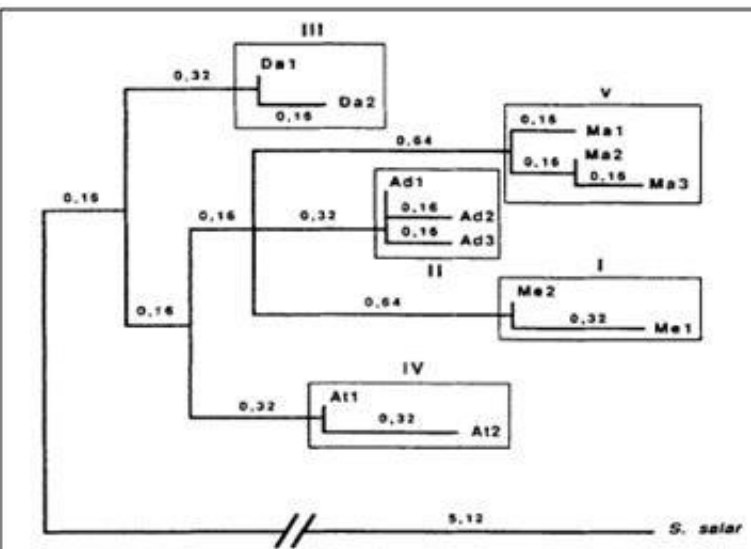

Figure 8. Sequences for two segments of the mtDNA control region, type Atl, from S.trutta. (Bernatchez et al., 1992).

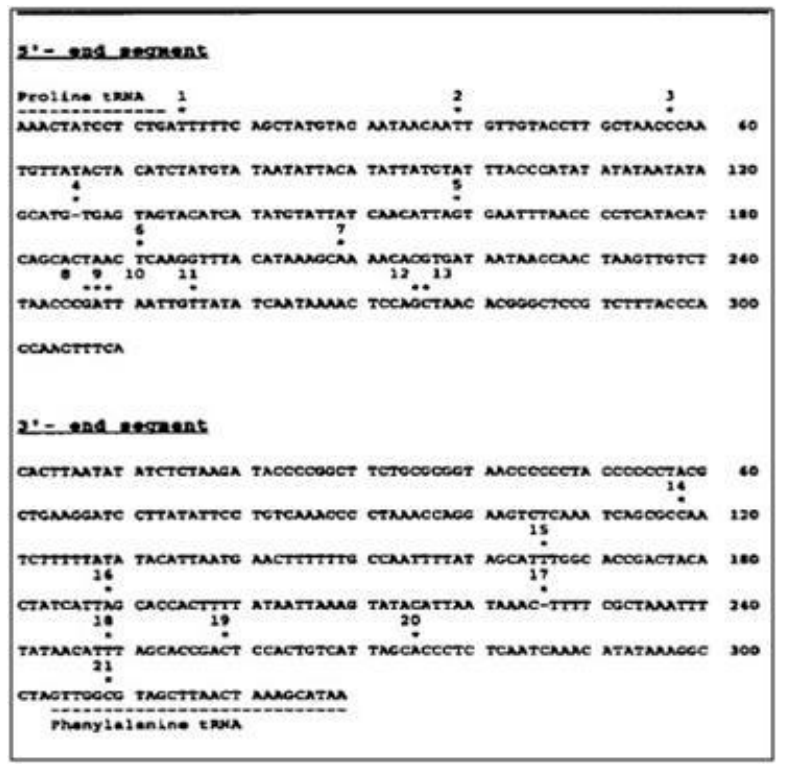

Figure 10. Unconshained branch-length phencF gram clustering 12 genotypes observed among 151 S.trutta mtDNA sequences. Branch lengths are given on the tree. Salmosalar was used as an outgroup taxon (Bernatchez et al., 1992).

The network was rooted using S.salar as an outgroup taxon. Open circles indicate mutational events and small character numbers refer to the variable nucleotide positions (Figure 8). Bold character numbers refer to the numbers of trees out of 16 in which particular groupings were observed (Bernatchez et al., 1992).

MtDNA and rDNA give different results in experimental tests. MtDNA phylogeny of cichlid fish is presented for the most taxonomically. Test results show that $16 \mathrm{~S}$ rDNA data establish with confidence relationships among major lineages of cichlids, with a

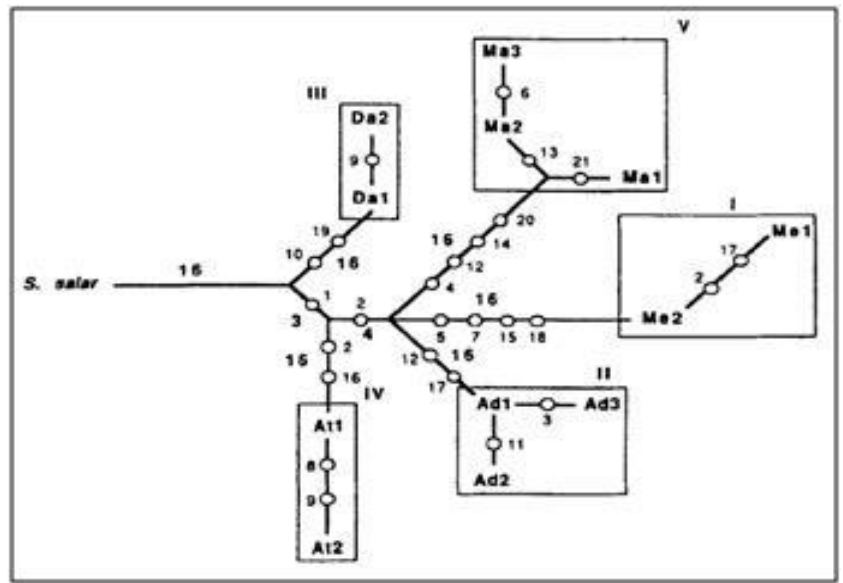

Figure 9. Variable nucelotide positions of 12 genotypes resolved among $151 \mathrm{~S}$. truttamt DNAs sequenced. Nucelotide at each position is given for genotype Atl. For other genotypes, nucleotides are given when different from ATl, while identity is indicated by dashes. Asterisks indicate deletions (or insertions) (Bernatchez et al., 1992).

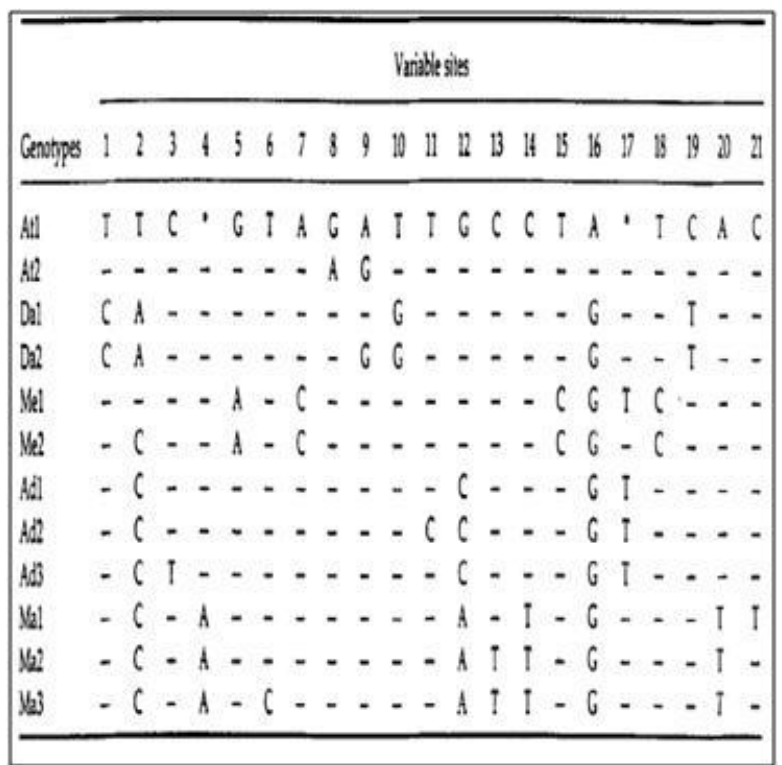

Figure 11. Majority-rule consensus network resulting from the 16 equally most parsimonious trees found by the MIX program.

general pattern congruent with previous morphological studies and less inclusive molecular phylogenies based on nuclear genes. Based on a large number of South American genera, the Neotropical cichlids are defined as a monophyletic assemblage and shown to harbor significantly higher levels of genetic variation than their African counterparts (Farias 1999). Skaala et al. (1990) claims farmed fish are genetically distinct from those of the native populations in the rivers.

In order to resolve divergences at many taxonomic levels, the mitochondrial cytochrome b (cyt-b) gene is widely used. Farias focuses mainly on the utility of cyt- 
b as a molecular marker for inferring phylogenetic relationship at various levels within the fish family Cichlidae. A total of 78 taxa were used representing all the major groups in the family Cichlidae (72 taxa) and other families from the suborders Labroidei and Percoidei. Relative rate tests detected significantly long branches for some taxa (LB taxa) which were composed mainly by dwarf Neotropical cichlids. An improvement of the phylogenetic signal, as shown by the four-cluster likelihood mapping analysis, and higher bootstrap values were obtained by excluding LB taxa. Despite some limitations of cyt-b as a phylogenetic marker, this gene either alone or in combination with other data sets yields a tree that is in agreement with the wellestablished phylogeny of cichlid fish (Farias 2001).

MtDNA Cytochrome $b$ (cyt- $b$ ) has been considered one of more useful genes for phylogenetic work, and is probably better-known mitochondrial gene with respect to structure and function of its protein product (Esposti et al., 1993).

\section{DISCUSSION}

Genetic enhancement and modification may be desirable for some wild populations, and there may be specialized application, such as artificial urban fishing environmental, where genetically modified wild fish may be of great benefit. Unique distinctive and representative populations would be identified, protected and preserved. Some areas and populations would be designed for genetic improvement to meet recreational goal or to restore or enhance genetically damaged populations. Some areas should be designed for the intentional mixing, deposition and propagation of many genotypes to form large diversified living gene banks for future utilization in fisheries and aquaculture.

Moreover, based on the all countries experience of dealing with the escapes problem, we recommend a range of measures for other countries to introduce effective anti-escape measures. We outline these principles below in 5 steps, and discuss how some of these measures may also be improved;

A. Obligatory reporting of all escape occurrences, involving: (1) a delineation of the marine-net cage technology interested (2) the number of escaped fish and their size; (3) classification of the functional influencing factor or environmental stipulations at the time of escape; and (4) an appraised cause of escape.

B. A determined mechanism to assemble, analyze and learn from the compulsory reporting. This knowledge must then be efficiently disseminated to equipment providers and fish farmers so improvements can be made.

C. Escapes determined by farmers are often inaccurate, we advise to use technical equipment to find out the causes of 'large-scale' escape incidents. Learning from each large-scale escape event would assist recommendations for the design and properties of sea-cage systems and help improve technical standards.

D. A technical standard table for sea-cage aquaculture equipment should be improved with an independent mechanism. These standards may upgrade aquaculture system.

E. Daily operations in fish farming such as correct anchoring, mooring, connecting net-cages to floaters have potential risks for escaping. Therefore, these key processes should be identified, and mandatory training of staff who undertakes these processes would likely reduce human errors that lead to escapes.

\section{REFERENCES}

Aquilino S.V.L, Tango J.M., Fontanilla, IKC, Pagulayan RC, Basiao ZU, Ong PS, Quilang JP, 2011. DNA Barcoding the ichthyofauna of Taal Lake, Philippines. Molecular Ecology Resources, 11: 612-619.

Avise J.C. 1994. Molecular Markers, Natural History and Evolution, Chapman and Hall NewYork.

Baharum S.N, Nurdalila A.Z, 2012. Application of 16s rDNA and cytochrome b ribosomal markers in studies of lineage and fish populations structure of aquatic species. Molecular Biology Reports, 39(5):5225-5232.

Bargelloni L., Alarcon J. A., Alvarez M. C., Penzo E., Magoulas A., Reis C. Patarnello T., 2003. Discord in the family Sparidae (Teleostei): divergent phylogeographical patterns across the AtlanticMediterranean divide. Blackwell Publıshıng Ltd. J .Evol.Biol. 16 (2003) pp. 1149-1158.

Bernatchez L., Colombani F., Dodson J. J., 1991. Phylogenetic relationships among the subfamily Coregoninae as revealed by mitochondrial DNA restriction analysis. Journal of Fish Biology, 39 (Supplement): 283-290.

Bernatchez L., Guyomard R., Bonhomme F., 1992. DNA sequence variation of the mitochondrial control region among geographically and morphologically remote European brown trout Salmotrutta populations. Molecular Ecology, 1:161173.

Bentsen, H.H., Gjerde, B. 1994. Design of fish breeding programs. In: Proceedings of the $5^{\text {th }}$ world congress of genetics applied to livestock production. Department of Animal Science. University of Guelph. Guelph. ON. 19. 553-39.

Birky, C.W., Fuerst, P. Maruyama, T. 1989. Organelle gene diversity under migration, mutation, and drift: equilibrium expectations, approach to equilibrium, effect of heteroplasmic cells, and comparison to nuclear genes. Genetics, 121(3): 613-627.

Brown, W.M. 1985. The mitochondrial genome of animals. In: McIntyre, R.J. Ed., Molecular Evolutionary Genetics, Plenum, New York, 95-130. 
Brugère, C., Ridler, N. 2004. Global aquaculture outlook in the next decades; an analysis of national aquaculture production forecasts to 2030. FAO Fisheries Circular No. 1001. Rome, FAO. 2004. 47p.

Cawthorn D-M, Steinman H. A., Witthuhn R. C. 2011. Establishment of a mitochondrial DNA sequence database for the identification of fish species commercially available in South Africa. Molecular Ecology Resources, 11: 979-991.

Cross, T. F. N. T. Challanain, D. N. 1991. Genetic characterisation of Atlantic salmon (Salmosalar) lines farmed in Ireland. Aquaculture, 9: 209-216.

Dimitriou, E., Katselis, G., Moutopoulos, D. K., Akovitiotis, C., Koutsikopoulos, C. 2007. Possible influence of reared gilthead sea bream (Sparusaurata, L.) on wild stocks in the area of the Messolonghi lagoon (Ionian Sea, Greece). Aquaculture Research, 38: 398-408.

Duarte, C.M., Marba, N., Holmer, M. 2007. Rapid domestication of marine species. Science 316: 382 383.

De Eyto, E., McGinnity, P., Consuegra, S., Coughlan, J., Tufto, J., Farrell, K., Megens, H.J., Jordan, W., Cross, T., Stet, R.J.M. 2007. Natural selection acts on Atlantic salmon major histocompatibility (MH) variability in the wild. Proceedings of the Royal Society of London series B 274: 861-869.

Esposti, D.M., De Vries, S., Crimi M., Ghelli A., Patarnello T., Meyer A. 1993. Mitochondrial cytochrome $b$ : evolution and structure of the protein. Biochim. Biophys. Acta., 1143:243-271.

Farias I. P., Orti G., Sampaio I., Schneider H., Meyer A. 2001. The Cytochrome $b$ Gene as a Phylogenetic Marker: The Limits of Resolution for Analyzing Relationships Among Cichlid Fishes. Journal of Molecular Evolution 53: 89-103.

Farias I.P., Meyer A., Ortí G., Sampaio, I. 2000. Total evidence: molecules, morphology, and the phylogenetics of cichlids fishes. J. Exp. Zool. (MolDevEvol) 288:76-92

Ferguson, A. J. B. T., Taggart, J. B., Prodöhl, P. A., McMeel, O., Thompson, C., Stone, C., Hynes, R. A. 1995. The application of molecular markers to the study and conservation of fish populations, with special reference to Salmo $s p$. Journal of Fish Biology, 47 (sA), 103-126.

Ferguson, A., Fleming, I., Hindar, K., Skaala, Ø., McGinnity, P., Cross, T.F., Prodöhl, P. 2007. Farm escapes. In: The Atlantic salmon: Genetics, Conservation and Management (Verspoor, E., Stradmeyer, L. \& Nielsen, J.L., eds.). Blackwell Publishing Ltd, pp. 357-398.

Flassch, J. P., Leborgne, Y. 1994. Introduction in Europe, from 1972 to 1980, of the Japanese Manila clam (Tapes philippinarum) and the effects on aquaculture production and natural settlement.In Introductions and Transfers of Aquatic
species.Selected papers from a Symposium Held in Halifax, Nova Scotia, 12-13 June 1990.

Gjedrem. T., 1998. Developments in fish breeding and genetics. Acta Agric. Scand. A. Animal Sci. 28:1926.

Gillanders B.M, Joyce T.C 2005. Distinguishing aquaculture and wild yellow tail kingfish via natural elemental signatures in otoliths. Mar. Freshw. Res., 56:693-704

Jensen Q., Fredheim A., Dempster T., Thorstad E. B., Uglem I. 2010. Escapes of fishes from Norwegian sea-cage aquaculture: causes, consequences and prevention, Aquaculture Environment Interactions, Published online August 2012, Vol.1: 71-83

Jørstad K. E., Van Der Meeren T., Paulsen O. I., Thomsen T., Thorsen A., Svåsand T. 2008 'Escapes' of eggs from farmed cod spawning in net pens: recruitment to wild stocks. Rev. Fish Sci. 16:285295.

Hebert P. D., Stoeckle M. Y., Zemlak T. S., Francis C. M. 2004. Identification of Birds through DNA Barcodes. PLoSBiol 2: e312.

Hubert N., Hanner R., Holm E., Mandrak N. E., Taylor E, et al. 2008. Identifying Canadian freshwater fishes through DNA barcodes. PLoS One. 3(6): e2490.

Kartavtsev Y. Ph., Sharina S. N., Goto T. , Balanov A. A. Hanzawa, N. 2009. Sequence diversity at cytochrome oxidase 1 (Co-1) gene among sculpins (Scorpaeniformes, Cottidae) and some other scorpionfish of Russia Far East with phylogenetic and taxonomic insights. Genes \& Genomics 31 (2): 183-197.

Knibb, W. 2000. Genetic Improvement of Marine Fish Which Method for Industry? Aquaculture Research, 31, 11-23.

Lakra WS, Verma MS, Goswamii M, Lal KK, Mohindra V, Punia P, Gopalakrishnan A, Singh KV, Ward RD, Hebert PDN, 2011. DNA Barcoding Indian Marine Fishes. Molecular Ecology Resources, 11: 60-71.

Magoulas, A., Tsimenides, N., Zouros, E. 1996. Mitochondrial DNA Phylogeny and the Reconstruction of the Population History of a Species: The Case of the European Anchovy (Engraulisencrasicolus) Mol. Biol. Evol., 13(1):178190.

Martins, C. Wasko, A. P. Oliveira, C., Foresti, F. 2003. Mitochondrial DNA variation in wild populations of Leporinuselongatus from the Paraná River basin. Genet. Mol. Biol., 26 (1):33-38.

Mecklenburg C. W., Moller P. R., Steinke D. 2011. Biodiversity of arctic marine fishes: Taxonomy and zoogeography. Marine Biodiversity, 41: 109-140.

Meyer, A. 1993. Evolution of mitochondrial DNA in fishes. In: Mochachka, P.W. and Mommsen, T.P. Eds., Biochemistry and molecular biology of fishes, Elsevier Press Amsterdam, New York, 1-38. 
Moe, H., Dempster T., Sunde L. M., Winther U., Fredheim A. 2007a.Technological solutions and operational measures to prevent escapes of Atlantic cod (Gadusmorhua) from sea-cages. Aquac. Res., 38:91-99.

Nicolas V., Schaeffer, B. Missoup A. D., Kennis, J. Colyn, M., Denys, C. Tatard, C. Cruaud, C. Laredo, C. 2012. Assessment of three mitochondrial genes (16S, Cytb, CO1) for identifying species in the Praomyini tribe (Rodentia: Muridae). PloS ONE 7(5): e36586.

Naylor R., Hindar K., Fleming Ian A., Goldburg, R., Williams, S., Volpe J., Whoriskey, F., Eagle J., Kelso D., Mangel, M., 2005. Fugitive salmon: assessing the risks of escaped fish from net-pen aquaculture. Bioscience, 55(5):427-437.

Norwegian Directorate of Fisheries, 2009.Statistics for Aquaculture 2008.Norwegian Directorate of Fisheries, Bergen. Available at: www.fiskeridir.no/fiskeridir/kystsone_og_havbruk/s tatistikk (accessed 6 Aug 2010) (in Norwegian)

Okumuş, I., and Çiftci, Y. 2003. Fish population genetics and molecular markers: II-molecular markers and their applications in fisheries and aquaculture. Turkish Journal of Fisheries and Aquatic Sciences, 3: 51-79.

Rodwell, L. D., Barbier, E. B., Roberts, C. M., McClanahan, T. R. 2003. The importance of habitat quality for marine reserve fishery linkages. Canadian Journal of Fisheries and Aquatic Sciences, 60(2): $171-181$

Scientific Advisory Committee, 2009. The status of Norwegian salmon stocks in 2009 and catch advice. Report from the Scientific Advisory Committee for Atlantic Salmon Management in Norway No. 1. Vitenskapeligrådforlakseforvaltning, Trondheim (In Norwegian with English summary)

Smith, M. D. 2007. Generating value in habitatdependent fisheries: the importance of fishery management institutions. Land Economics, 83(1):59-73.

Sola, L., Moretti, A., Crosetti, D., Karaiskou, N., Magoulas, A., Rossi, A. R., Rye, M., et al. 2007. Gilthead seabream-Sparusaurata. In Genetic Effects of Domestication, Culture and Breeding of Fish and Shellfish, and their Impacts on Wild Population, pp. 47-54. Ed. by T. Svasand, D. Crosetti, E. Garcia-Vazquez, and E. Verspoor. Genimpact Final Scientific Report (EU contract n. RICA-CT-2005-022802). 176 pp.

Soto D., Jara F., Moreno C. 2001. Escaped salmon in the inner seas, southern Chile: facing ecological and social conflicts. Ecol. Appl., 11:1750-1762.
Skaala, O., Dahle, G., Jorstad, K. E., Naevdal, G. 1990. Interactions between natural and farmed fish populations: information from genetic markers. Journal of Fish Biology, 36: 449-460.

Tacon, A. J. 2003. Aquaculture production trends analysis. FAO Fisheries Circular, (Rev. 2), 5-29.

Toledo Guedes K., Sanchez-Jerez P., Gonzalez-Lorenzo G., Brito Hernandez A. 2009. Detecting the degree of establishment of a non-indigenous species in coastal ecosystems: sea bass Dicentrarchuslabrax escapes from sea cages in Canary Islands (Northeastern Central Atlantic). Hydrobiologia, 623:203-212.

Valland, A. 2005. The causes and scale of escapes from salmon farming. In: Interactions between aquaculture and wild stocks of Atlantic salmon and other diadromous fish species: science and management, challenges and solutions. ICES/NASCO Bergen 18-21 October 2005, pp. 15.

Utter, F., Epifanio, J. 2002. Marine aquaculture: genetic potentials and pitfalls. Reviews in Fish Biology and Fisheries, 12:59-77.

Ward R. D., Zemlak T. S., Innes B. H., Last P. R., Hebert P. D. 2005. DNA barcoding Australia's fish species. Philos. Trans. R. Soc. Lond. B. Biol. Sci. 360: 1847-1857.

Lee A. Weigt, Carole C. Baldwin, Amy Driskell, David G. Smith, Andrea Ormos, Eric A. Reyier, 2012. Using DNA Barcoding to Assess Caribbean Reef Fish Biodiversity: Expanding Taxonomic and Geographic Coverage. PloS ONE 7(7): e41059. doi:10.1371/journal.pone.0041059.

Weber, E.D., Fausch, K. D. 2003. Interactions between hatchery and wild salmonids in streams: differences in biology and evidence for competition. Canadian Journal of Fisheries and Aquatic Sciences, 60: 1018-1036.

Welcomme R.L., Bartley, D. M. 1998. Current approaches to the enhancement of fisheries. Fisheries Management and Ecology, 5: 351-382.

Wilson, A.C., Cann, R.L., Carr, S.M., George, M., Gyllensten, U.B., Helm-Bychowski, K.M., Higuchi, R.G., Palumbi, S.R., and Prager, E.M. 1985. Mitochondrial DNA and two perspectives on evolutionary genetics. Biological Journal of Linnean Society, 26(4):375-400.

Youngson, A. F., Jordan, W. C., Hay, D. W. 1994. Homing of Atlantic salmon (Salmosalar L.) to a tributary spawning stream in a major river catchment. Aquaculture, 121: 259-267. 